\title{
ANTIBACTERIAL EFFECT OF VIRGIN COCONUT OIL ON THE VIABILITY OF CHROMOGENIC BACTERIA THAT CAUSES DENTAL BLACK STAIN IN CHILDREN
}

\author{
ADITA GAYATRI, EVA FAUZIAH, MARGARETHA SUHARSINI
}

Department of Pediatric Dentistry, Faculty of Dentistry, Universitas Indonesia, Jakarta, Indonesia. Email: eva_dens@yahoo.com

Received: 16 September 2017, Revised and Accepted: 3 October 2017

ABSTRACT

Introduction: Virgin coconut oil (VCO) is a natural antibacterial agent with the ability to kill microorganisms whose cell membranes contain lipids, including Gram-positive and Gram-negative bacteria, such as Actinomyces sp. and Prevotella spp. No study on the antibacterial effects of VCO on the chromogenic bacteria that causes dental black stains.

Objective: To analyze the effects of VCO, which administered in various concentrations to Actinomyces sp. and Prevotella sp.

Methods: Actinomyces sp. and Prevotella sp. were isolated from the dental plaque of a child diagnosed with black stain. Each streak of bacteria was cultured on a selective medium and confirmed visually and through Gram staining. Each bacterial culture was exposed to VCO in concentrations of $12.5 \%, 25 \%, 50 \%$, and $100 \%$. Afterward, viability testing with a methyl-thiazolyl-tetrazolium assay was conducted, and the results were read using an Enzyme-linked immunosorbent assay reader.

Results: The administration of $12.5 \%$ VCO reduced bacterial viability; however, $25 \%$ VCO significantly reduced the viability of Actinomyces sp. and $100 \%$ VCO significantly reduced the viability of Prevotella sp.

Conclusion: Actinomyces sp. is more sensitive to VCO than Prevotella sp.

Keywords: Chromogenic bacteria, Dental black stain, Cell viability, Virgin coconut oil.

(C) 2017 The Authors. Published by Innovare Academic Sciences Pvt Ltd. This is an open access article under the CC BY license (http://creativecommons. org/licenses/by/4. 0/) DOI: http://dx.doi.org/10.22159/ijap.2017.v9s2.20

\section{INTRODUCTION}

Dental stains are common conditions, and they are generally related to clinical conditions and esthetics [1]. Dental stains found in children are categorized as black stains and are caused by anerobic chromogenic bacteria, namely, Actinomyces sp. and Prevotella sp. [2]. These bacteria bind with the pellicle and produce extrinsic stains/discolorations on the dental surface according to the underlying tone $[3,4]$.

Dental black stain has clinical characteristics, such as dark dots that form an interrupted line on two-thirds of the cervix of the tooth crown, following the contour of the gingiva, and adhering tenaciously to the dental surface $[5,6]$.

Several studies have been conducted to identify the prevalence and etiological factors of dental black stain. Previous studies conducted in Jakarta in 2012 revealed that the ferrum content and amount of Actinomyces spp. is higher in the saliva of children with black stain than in children without black stain $[7,8]$.

Dental black stain poses two main challenges to dentists: Identifying the etiology and managing dental black stain. Few studies address dental black stain because the etiology has not been identified. Common dental black stain treatments include scaling and polishing the teeth $[6,9]$. However, black stain tends to recur regardless of the patient's good oral hygiene [10]. This recurrence may be attributed to above normal quantities of chromogenic bacteria on the plaque and saliva of the teeth in children with dental black stain [11]. Which suggests that an antibacterial agent is required to inhibit the bacterial growth that causes a black stain.

These antibacterial agents may be derived from chemical compounds or natural ingredients, such as coconuts [12]. Processed coconuts can be made into therapeutic compounds, including coconut oil or virgin coconut oil (VCO), due to the high content of lauric acid, which has properties that kill a variety of microorganisms whose cell membranes contain lipid acid, such as Gram-positive or Gram-negative bacteria. The nonpolar nature of lauric acid enables it to penetrate into the bacteria's cell membrane, damaging the phospholipid bilayers, and causing cell lysis $[13,14]$.

Studies on the dental benefits of VCO are limited, especially with regard to the prevention of dental black stain. However, previous studies on the effect of VCO in concentrations of $12.5 \%, 25 \%$, and $50 \%$ on the growth and protein profile of Streptococcus mutans revealed a decline in the colony counts and a significant change in the protein profile with the increasing concentrations of VCO [15] which motivated a deeper investigation into the antibacterial effect of VCO on the viability of Actinomyces spp. and Prevotella spp., the primary chromogenic bacteria that cause dental black stain in children.

\section{METHODS}

This study is an in vitro laboratory experiment that tested the viability of Actinomyces spp. and Prevotella spp. after the administration of VCO in various concentrations. With the approval from Ethical Committee of the Faculty of dentistry Universitas Indonesia, the subject, a child diagnosed with dental black stain, was identified. The inclusion criteria were as follows: A child aged 4-11 years with a good oral condition, the presence of black stain on at least 10 tooth enamel surfaces, and the participant's parental consent. The exclusion criteria included: Poor oral hygiene, high incidence of caries (def- $t>5$ ), subjects under medical care or taking medicines, and subjects with plaque samples that were difficult to harvest.

Plaque sampling was conducted on a child diagnosed with black stain. Then, the sample was cultured in a selective medium, and a 
colony assessment was conducted. The experimental and laboratory study with sample measurement used the Federer Formula to obtain three samples. Then, Duplo was conducted, so each treatment was six samples. The next step was to visually confirm with Gram staining method. Following identification, 200 ul of bacteria was suspended on a 96-well plate and incubated in an anerobic setting for $20 \mathrm{hrs}$ at $37^{\circ} \mathrm{C}$. While the bacteria were in the incubator, a VCO testing solution was created in the following concentrations: $12.5 \%, 25 \%, 50 \%$, and $100 \%$. Dilution of the VCO was completed using phosphate buffer solution. Then, the VCO solutions were homogenized to obtain a homogenous solution.

After 20 hrs, 200 ul of Actinomyces spp. and Prevotella spp. suspended on 96-well plates were exposed to 100 ul VCO in various concentrations. Bacteria exposed to the positive control $(0.2 \%$ chlorhexidine gluconate $)$ and the negative control (without testing material) were also prepared. Then, bacteria were incubated for 60 minutes in an anerobic setting at $37^{\circ} \mathrm{C}$. Finally, an methyl-thiazolyl-tetrazolium (MTT) solution was poured into each well of tested material, and the tested material solutions were incubated for $3 \mathrm{hrs}$. The results of the MTT testing were read using an Enzyme-linked-immunosorbent-assay reader with the wavelength $490 \mathrm{~nm}$. The absorption score or optical density (OD) of the treatment and control groups were used in the following formula to calculate the cell viability percentage score.

\section{$<$ H1 $>$ RESULTS}

This study sought to identify the antibacterial effect of VCO on the bacterial viability of Actinomyces spp. and Prevotella spp., which cause a dental black stain in children. Data normality was tested using the Shapiro-Wilk test and data score showed a normal distribution. Afterward, the data for both the Actinomyces spp. and Prevotella spp. after the administration of VCO in various concentrations were analyzed using one-way ANOVA to identify any discrepancies between each bacterial viability score. An unpaired $t$-test was used to identify the differences in viability scores between the Actinomyces spp. and Prevotella spp. after the administration of VCO in various concentrations.

Table 1 summarizes the differences in the Actinomyces spp. viability scores after the administration of the antibacterial agent in various concentrations. The ANOVA significance was calculated as 0.000 $(\mathrm{p}<0.05)$, so at least two groups had significantly different viability means. The results of the one-way ANOVA reveal significant differences, so post hoc testing was conducted to determine which intergroup had the different mean viability scores.

Table 2 summarizes the results of the post hoc analysis of Actinomyces spp. A statistically significant difference in the bacterial viability of Actinomyces spp. was found between: The negative control group and the treatment group with $25 \% \mathrm{VCO}$, the positive control group and the treatment group with $50 \%$ VCO, the treatment group with $100 \%$ VCO and the treatment group with 50\% VCO, the treatment group with 100\% VCO and the treatment group with $25 \%$ VCO, the treatment group with $100 \%$ VCO and the treatment group with $12.5 \%$ VCO, the treatment group with $50 \%$ VCO and the treatment group with $25 \%$ VCO, and the treatment group with $50 \%$ VCO and the treatment group with $12.5 \%$ VCO (p<0.05).

Table 3 summarizes differences in the bacterial viability values of Prevotella spp. after the administration of the antibacterial VCO in various concentrations. The ANOVA significance was calculated as $0.000(\mathrm{p}<0.05)$, so at least two groups had significantly different viability means.

The results of the one-way ANOVA reveal significant differences, so post hoc testing was conducted to determine which intergroup had the different mean viability scores.

Table 4 summarizes the results of the post hoc analysis of Prevotella spp. A statistically significant difference in the bacterial viability of
Table 1: Differences in bacterial viability of Actinomyces spp. toward administration of VCO in various concentrations

\begin{tabular}{llll}
\hline Treatment group & $\mathbf{n}$ & $\begin{array}{l}\text { Viability } \\
\text { means } \pm \text { SD (\%) }\end{array}$ & p \\
\hline Negative control & 3 & 100.00 & $<0.001$ \\
Positive control $(0.2 \%$ CHX) & 3 & $29.97 \pm 3.51$ & \\
$100 \%$ VCO & 3 & $32.58 \pm 2.75$ & \\
$50 \%$ VCO & 3 & $40.02 \pm 2.64$ & \\
$25 \%$ VCO & 3 & $63.84 \pm 4.01$ & \\
$12.5 \%$ VCO & 3 & $83.54 \pm 7.14$ & \\
\hline
\end{tabular}

One-way ANOVA testing, ${ }^{*}$ significant score based on $\mathrm{p}<0.05$. VCO: Virgin coconut oil, SD: Standard deviation

Table 2: Post hoc analysis of differences in bacterial viability of Actinomyces spp. in treatment intergroups

\begin{tabular}{lll}
\hline Treatment group & $\begin{array}{l}\text { Difference } \\
\text { in viability } \\
\text { means (\%) }\end{array}$ & p \\
& 36.16 & $<0.001$ \\
\hline $\begin{array}{l}\text { Negative control versus 25\% VCO } \\
\text { Negative control versus 12.5\% VCO }\end{array}$ & 16.47 & 0.637 \\
Positive control (0.2\% CHX) versus & 2.62 & 0.952 \\
100\% VCO & & \\
Positive control (0.2\% CHX) versus & 10.05 & 0.004 \\
$50 \%$ VCO & & \\
100\% versus 50\% VCO & 7.44 & 0.011 \\
100\% versus 25\% VCO & 31.27 & $<0.001$ \\
100\% versus 12.5\% VCO & 50.96 & 0.010 \\
$50 \%$ versus 25\% VCO & 23.82 & $<0.001$ \\
$50 \%$ versus 12.5\% VCO & 43.52 & 0.021 \\
$25 \%$ versus 12.5\% VCO & 19.69 & 0.428 \\
\hline Post & & \\
\hline
\end{tabular}

Post hoc Tamhane's testing, *significant score based on $\mathrm{p}<0.05$. VCO: Virgin coconut oil

Table 3: Difference in bacterial viability of Prevotella sp. with administration of VCO in various concentrations

\begin{tabular}{llll}
\hline Treatment group & $\mathbf{n}$ & $\begin{array}{l}\text { Viability } \\
\text { means } \pm \text { SD (\%) }\end{array}$ & p \\
\hline Negative control & 3 & 100.00 & $<0.001$ \\
Positive control $(0.2 \%$ CHX) & 3 & $37.24 \pm 4.23$ & \\
$100 \%$ VCO & 3 & $65.35 \pm 11.02$ & \\
$50 \%$ VCO & 3 & $84.15 \pm 13.19$ & \\
$25 \%$ VCO & 3 & $89.04 \pm 9.28$ & \\
$12.5 \%$ VCO & 3 & $96.83 \pm 5.74$ & \\
\hline
\end{tabular}

One-way ANOVA testing, ${ }^{*}$ significant value based on $\mathrm{p}<0.05$. VCO: Virgin coconut oil, SD: Standard deviation

Table 4: Post hoc analysis of difference in bacterial viability of Prevotella spp. in treatment intergroups

\begin{tabular}{lll}
\hline Treatment group & $\begin{array}{l}\text { Difference } \\
\text { in viability } \\
\text { means (\%) }\end{array}$ & p \\
& 34.65 & 0.009 \\
\hline Negative control versus 100\% VCO & 15.85 & 0.388 \\
Negative control versus 50\% VCO & 10.96 & 0.406 \\
Negative control versus 25\% VCO & 3.17 & 0.982 \\
Negative control versus 12.5\% VCO & 28.11 & 0.013 \\
Positive control (0.2\% CHX) versus & & \\
$100 \%$ VCO & 18.80 & 0.038 \\
100\% versus 50\% VCO & 23.69 & 0.005 \\
100\% versus 25\% VCO & 31.48 & 1.000 \\
100\% versus 12.5\% VCO & 4.89 & 0.657 \\
$50 \%$ versus 25\% VCO & 12.68 & 0.846 \\
\hline $25 \%$ versus 12.5\% VCO & 7.78 & \\
\hline
\end{tabular}

Post hoc Tamhane's testing, *significant value based on p<0.05. VCO: Virgin coconut oil 
Prevotella spp. was found between: The negative control group and the treatment group with $100 \% \mathrm{VCO}$, the positive control group and the treatment group with $100 \%$ VCO, the treatment group with $100 \%$ VCO and the treatment group with $25 \% \mathrm{VCO}$, and the treatment group with $100 \%$ VCO and the treatment group with $12.5 \%$ VCO $(p<0.05)$.

To identify the difference in the viability values of Actinomyces spp. and Prevotella spp. after the administration of VCO in various concentrations, unpaired $t$-tests were conducted.

Table 5 summarizes a significant difference between the bacterial viability of Actinomyces spp. and Prevotella spp. after the administration of the $100 \%, 50 \%$, and $25 \%$ VCO concentrations $(\mathrm{p}<0.05)$.

\section{DISCUSSION}

This study was conducted to identify the antibacterial effect of VCO on the bacterial viability of Actinomyces spp. and Prevotella spp., which cause dental black stain in children. Actinomyces spp. and Prevotella spp. were cultured in a selective medium.

The results of the bacterial culture were supported by the literature, which states that Actinomyces spp. and Prevotella spp. are primary chromogenic bacteria that play a role in the formation of dental black stain in children $[1,11,16]$.

The antibacterial agent used in this study was VCO made using the fermentation method as it is a natural antibacterial agent due to its abundance of lauric acid (up to 61.07\%). Lauric acid is a natural antibacterial agent that can kill microorganisms whose cell membranes contain lipid acids $[13,17]$. The VCO used in the study was in the following concentrations: $100 \%, 50 \%, 25 \%$, and $12.5 \%$. Previous studies showed that VCO in concentrations of $12.5 \%, 25 \%$, and $50 \%$ has had positive effects on the growth and protein profile of S. mutans [15].

One-way to test the antibacterial effect of an agent is cytotoxicity testing. The cytotoxicity testing used in this study was an MTT assay, which is a standard colorimetric laboratory test that measures viable cells and is stated in OD. The OD value is comparable to the number of viable cells and is, therefore, used to calculate the percentage of viable cells after exposure to an antibacterial agent $[18,19]$.

In this study, exposure to VCO was completed during the 20 -hr biofilm formation phase or the active accumulative phase, which is supported by previous studies that state that in the active accumulative phase, active growth occurs, enabling antibacterial agents to kill bacteria. In the 4-hr biofilm formation phase (adhesive phase), exposure to antibacterial agents did not reveal bacterial growth, and bacterial viability was not detected. In the 24-hr biofilm formation phase (maturation phase), bacterial growth slows, increasing the formation of extracellular polysaccharides, and the bacteria's resistance to antibacterial agents increases [20]. The exposure of Actinomyces spp. and Prevotella spp.

Table 5: Difference in bacterial viability of Actinomyces spp. and Prevotella spp. toward administration of VCO in various concentrations

\begin{tabular}{lllll}
\hline $\begin{array}{l}\text { VCO } \\
\text { concentration }\end{array}$ & n & $\begin{array}{l}\text { Viability } \\
\text { means } \pm \text { SD (\%) }\end{array}$ & p \\
\hline $100 \%$ VCO & Actinomyces sp. & 3 & $32.58 \pm 2.75$ & 0.001 \\
& Prevotella sp. & 3 & $65.35 \pm 11.02$ & \\
$50 \%$ VCO & Actinomyces sp. & 3 & $40.02 \pm 2.64$ & 0.001 \\
& Prevotella sp. & 3 & $84.15 \pm 13.19$ & \\
$25 \%$ VCO & Actinomyces sp. & 3 & $63.84 \pm 4.01$ & 0.001 \\
& Prevotella sp. & 3 & $89.04 \pm 9.28$ & 0.121 \\
$12.5 \%$ VCO & Actinomyces sp. & 3 & $83.54 \pm 7.14$ & 0.121 \\
& Prevotella sp. & 3 & $96.83 \pm 5.74$ & \\
\hline
\end{tabular}

Unpaired $t$-test, *significant value based on $\mathrm{p}<0.05$. VCO: Virgin coconut oil,

SD: Standard deviation to VCO was followed by a 60-minute incubation period. The length of exposure was based on previous studies that stated that the maximal bacteria inhibition effect of antibacterial agents requires exposure to the antibacterial agent for 60 minutes [21].

The in vitro administration of VCO resulted in a decline in the bacterial viability of Actinomyces spp. and Prevotella spp. The decline in bacterial viability after the administration of VCO is due to its antibacterial content, namely, the lauric acid that kills a wide variety of microorganisms whose cell membranes contain lipid acids, such as Gram-positive and Gramnegative bacteria $[15,17]$. Lauric acid is a nonpolar, saturated lipid acid. The nonpolar properties enable lauric acid to penetrate the bacteria's cell membrane, destroying the phospholipid bilayer, at which point bacterial cell lysis ensues [22,23]. The ability of VCO to kill bacteria is supported by previous studies that use a novel two-color fluorescent assay to identify bacterial viability and electron microscopy to show that lipids kill bacteria by disintegrating the cell membrane [14]

The statistical analysis (Tables 1 and 3) shows that each VCO concentration causes a decline in the bacterial viability value. The lowest viability occurred when the bacteria were exposed to the $100 \%$ VCO concentration, whereas the highest viability value occurred when the bacteria were exposed to the $12.5 \%$ VCO concentration [24].

These findings support the literature that states that the effectiveness of antibacterial agents in killing bacteria has a correlation with the effect caused. This correlation can be explained using the hyperbolic curve. If the concentration is increased, the maximal effect of the agent will increase. However, after exceeding the maximal value, an increase in the dose will not augment the effectiveness of the antibacterial [25].

The statistical analysis in Table 2 summarizes no significant difference in the bacterial viability of Actinomyces spp. between the negative control and the treatment group with the $12.5 \%$ VCO, which may mean that although $12.5 \%$ VCO decreases the bacterial viability of Actinomyces spp., the concentration is not high enough kill Actinomyces spp. However, a significant difference was found in the bacterial viability of Actinomyces spp. between the $25 \%$ VCO treatment group and the negative control group. Therefore, in this study, the minimum concentration of VCO necessary to kill Actinomyces spp. is a 25\% [24].

The statistical analysis in Table 4 summarizes no significant difference in the bacterial viability of Prevotella spp. between the negative control; the treatment control; and the 50\%, 25\%, and $12.5 \%$ VCO groups. Lower concentrations of $\mathrm{VCO}$ are not adequate as antibacterial agents in killing Prevotella spp. Thus, this study concludes that a 100\% VCO concentration is necessary to kill Prevotella spp. [24].

This study found no significant difference in the bacterial viability of Actinomyces spp. between the positive control group $(0.2 \%$ chlorhexidine gluconate, the best broad-spectrum antibacterial agent against Gram-positive and Gram-negative bacteria) and the treatment group with $100 \%$ VCO. Therefore, $100 \%$ VCO has an antibacterial effect comparable to that of $0.2 \%$ chlorhexidine gluconate on Actinomyces spp. The VCO testing on Prevotella spp. showed a significant difference in viability between the positive control group and the treatment group with $100 \%$ VCO. Therefore, the administration of $100 \%$ VCO is not as effective as $0.2 \%$ chlorhexidine gluconate in killing Prevotella spp. $[24,26]$.

The statistical analysis in Table 5 summarizes that the decline in the bacterial viability of Actinomyces spp. is higher than Prevotella spp. after the admiration of various concentrations of VCO. This finding is supported by the literature, which states that Gram-positive bacteria are more susceptible to antibacterial agents than Gram-negative bacteria $[22,23]$.

The structure of the simple cell linings of Gram-positive bacteria enables the antibacterial VCO to penetrate the cell membrane, where 
intracellular material leakage and cell biosynthesis impairment causes bacterial cells lysis $[23,27]$.

Gram-negative bacteria, such as Prevotella spp., have cell membranes composed of lipopolysaccharides and lipoprotein, which are bound to peptidoglycan linings. Lipopolysaccharides and peptidoglycan function as the bacteria cell's defense system by selecting the foreign substances that enter the cell. The penetration of the antibacterial VCO into the Gram-negative bacteria may be inhibited due to the presence of lipoprotein, which contains a hydrophilic protein at the outer membrane of the bacterial cells, commonly referred to as porins, preventing the antibacterial agent from entering the cell [27].

This study is preliminary and involves direct contact between the antibacterial solutions and the Actinomyces spp. and Prevotella spp., so it does not describe the real situation in the oral cavity. Therefore, further studies that use saliva biofilm harvested from healthy volunteers are necessary to identify the actual oral environment. The results of this study can serve as the foundation for further in vivo studies that assess the antibacterial effect of VCO on the dental black stain.

\section{CONCLUSIONS}

Based on the in vitro study results, the following conclusions can be made:

1. There is a difference in the bacterial viability of Actinomyces spp. and Prevotella spp. after the administration of VCO in various concentrations;

2. Each augmentation of VCO concentration causes a reduction in the bacterial viability of Actinomyces spp. and Prevotella spp.;

3. The antibacterial effect of VCO on the decline in the viability value of Actinomyces spp. is higher than that of Prevotella spp.;

4. The administration of $12.5 \%$ VCO reduced bacterial viability; however, the reduction of the bacterial viability of Actinomyces spp. is significant after the administration of $25 \% \mathrm{VCO}$, and the reduction of the bacterial viability of Prevotella spp. is significant after the administration of $100 \%$ VCO.

\section{ACKNOWLEDGMENT}

The publication of this manuscript is supported by Universitas Indonesia.

\section{REFERENCES}

1. França-Pinto CC, Cenci MS, Correa MB, Romano AR, Peres MA, Peres KG, et al. Association between black stains and dental caries in primary teeth: findings from a Brazilian population-based birth cohort. Caries Res 2012;46:170-6.

2. Newman MG, Takei HH, Carranza FA. Carranza's Clinical Periodontology. New York: Elsevier; 2002. p. 188.

3. Brook AH, Smith RN, Lath DJ. The clinical measurement of tooth colour and stain. Int Dent J 2007;57:324-30.

4. Addy M, Moran J. Mechanisms of stain formation on teeth in particular associated with metal ions and antiseptics. Adv Dent Res 1995;9:450-6.
5. Zyla T, Kawala B, Antoszewska-Smith J, Kawala M. Black stain and dental caries: a review of the literature. Biomed Res Int 2015;2015:469392.

6. Ronay V, Attin T. Black stain-a review. Oral Health Prev Dent 2011;9:37-45

7. Rustan Y. Kuantitas Bakteri Actinomyces Sp Di Saliva Anak Dengan Black Stain Pada Permukaan Email Gigi, Thesis, Universitas Indonesia; 2012. p. 22-2.

8. Sella. Kadar Ferum Dalam Saliva Pada Anak Dengan Dental Black Stain, Thesis, Universitas Indonesia; 2012. p. 16-22.

9. Jeffrey AD, McDonald RE. Dentistry for the Child and Adolescent. St Louis: C.V. Mosby Elsevier; 2011.

10. Wilkins EM. Clinical Practice of the Dental Hygienist. Philadelphia, PA: Lippincott Williams ans Wilkins; 2005. p. 316-7.

11. Slots J. The microflora of black stain on human primary teeth. Scand J Dent Res 1974;82:484-90.

12. Puneeta D. Coconut: The life tree. Ind J Altern Dent $2013 ;: 60-2$

13. Silalahi J, Yademetripermata,Putra E.Antibacterial activity hydrolized virgin coconut oil. Asian J Pharm Clin Res 2014;7:90-4

14. Batovska DI, Todorova IT, Tsvetkova IV, Najdenski HM. Antibacterial study of the medium chain fatty acids and their 1-monoglycerides: Individual effects and synergistic relationships. Pol J Microbiol 2009;58:43-7.

15. Hasrianti E. Pengaruh Virgin Coconut Oil (VCO) Hasil Fermentasi Terhadap Pertumbuhan Dan Profil Protein Streptococcus mutans Serotipe C Secara in Vitro, Essay, Universitas Indonesia; 2007. p. 23-9.

16. Li Y, Zhang Q, Zhang F, Liu R, Liu H, Chen F. Analysis of the microbiota of black stain in the primary dentition. PLoS One 2015;10:e137030.

17. Peedikayil FC, Sreenivasan P, Narayanan A. Effect of coconut oil in plaque related gingivitis-a preliminary report. Niger Med J 2015;56:143-7.

18. Terry L, Richard A, Andrew L, Duellmann S, Helene AB, Tracy JW, et al. Cell viability assays. Assay Guidance Manual. USA: National Library of Medicine; 2013

19. Ahmadian S, Barar J, Saei AA, Fakhree MA, Omidi Y. Cellular toxicity of nanogenomedicine in MCF-7 cell line: MTT assay. J Vis Exp 2009;26:1191

20. Mah TF, O’Toole GA. Mechanisms of biofilm resistance to antimicrobial agents. Trends Microbiol 2001;9:34-9.

21. Kim JE, Kim HE, Hwang JK, Lee HJ, Kwon HK, Kim BI. Antibacterial characteristics of Curcuma xanthorrhiza extract on Streptococcus mutans biofilm. J Microbiol 2008;46:228-32.

22. Johnson AG, Richard Z, Thomas JF, et al. General properties of microorganisms. In: Microbiology and Immunology. $4^{\text {th }}$ ed. Philadelphia, PA: Lippincott Williams and Wilkins; 2002. p. 16

23. Guilhelmelli F, Vilela N, Albuquerque P, Derengowski Lda S, SilvaPereira I, Kyaw CM. Antibiotic development challenges: the various mechanisms of action of antimicrobial peptides and of bacterial resistance. Front Microbiol 2013;4:353.

24. Sopiyudin D. Statistik Untuk Kedokteran dan Kesehatan. $6^{\text {th }}$ ed. Jakarta: Epidemiologi Indonesia; 2014

25. Aronson JK. Concentration-effect and dose-response relations in clinical pharmacology. Br J Clin Pharmacol 2007;63:255-7.

26. Ronanki S, Kulkarni S, Hemalatha R, Kumar M, Reddy P. Efficacy of commercially available chlorhexidine mouthrinses against specific oral microflora. Indian J Dent Res 2016;27:48-53.

27. Mangunwardoyo W, Usia T. Antimicrobial and identification of active compound Curcuma xanthorriza. Int J Basic Appl Sci 2012;12:69-78. 